\title{
Computer-mediated discourse analysis: an overview of leading vocabulary teaching strategies
}

\author{
Zinaida Vozgova \\ Faculty of English Philology \\ South Ural State Humanitarian Pedagogical University \\ Lenin prospect, 69, 454080 Chelyabinsk \\ Russian Federation \\ e-mail: zinaidavozgova@ mail.ru \\ Olga Afanasyeva \\ Faculty of English Philology \\ South Ural State Humanitarian Pedagogical University \\ Lenin prospect, 69, 454080 Chelyabinsk \\ Russian Federation \\ e-mail: afanasevaou@cspu.ru
}

\begin{abstract}
Rapid advances in information technology and proliferation of social media services have caused a radical transformation of human communication. Having created a social media presence people engage in computer-mediated communication, set their own goals as well as perfect their knowledge of English as a global language. The richness and diversity of computer-mediated discourse is concentrated in multiple online experiences and therefore enables to study a great number of linguistic changes. Various studies of computer-mediated discourse analyze socio-psychological characteristics in coherent sequences of sentences, propositions, speech or turns-at-talk. The given article aims at presenting vocabulary teaching strategies to new computer-mediated language and their influence on students' acquisition. Our contribution provides an overview of the recent new entries of computer-mediated vocabulary in online crowdsourced dictionaries. The main ways of forming new words as well as wide-spread semantic changes are viewed (acronyms, compounds, suffixes, blended words, conversion, etc.) Computer-mediated vocabulary teaching in the classroom covers change, diversity, disputes in economical, political, social spheres (such as narcissistic tendencies, emotional correctness, excessive use of social media and increasing reliance on technology, equal rights movement, task-based employment, etc). As the social media universe strives for a thorough integration with the user's life language learners are expected to embrace the latest changes in linguistic norms and devise an appropriate philosophy of language management.
\end{abstract}

\section{Introduction}

The issue of computer-mediated communication (CMC) traditionally refers to those communications occurring via social media services, e-mail, instant messaging, online forums, etc which provide a lot of opportunities for language learners to pick up new vocabulary as well as practice listening, reading, writing or speaking skills. The rise of social media is causing all sorts of rapid changes in the language which is evolving all the time. Social mobility, globalization, and the use of English as the global lingua franca make these changes even more complicated. The social media universe has become indispensable in modern life and strives for more thorough integration with the user's life (Lisin et al. 2014; Zielińska 2016; or Ragulina et al. 2018). One-third of humanity could be considered digital natives - they all use smartphones, messaging and status updates are often more natural than having a live conversation. When we want to talk to friends of family members we log onto Facebook or WhatsApp and send them a message rather than going to their houses (Mitsche and Strielkowski 2016; Strielkowski 2017). Virtually everyone is tweeting, posting and hash-tagging. Facebook, Instagram, WhatsApp as the truly global social networks popularizing the idea of social media are essentially fuelling growth of linguistic changes. When people have something to say publicly or aspire to participate in big conversations online they resort to Twitter with $300+$ million active user base. Tweets from world leaders and CEOs might have far-reaching consequences but at the same time they might instigate global social movements as well as affect changes around the globe (e.g. \#metoo phenomenon, \#TakeAKnee, \#Covfefe, \#YemenInquiryNow, etc). Thus, in a world where social interactions are filled with hashtags or emojis and projected through a front-facing camera, service providers are not merely the connective tissue of the society they are changing linguistic norms as well. 
In order to teach language learners relevant vocabulary of computer-mediated discourse quantitative analysis should be employed to evaluate linguistic features and their correlation to sociological variables. There are constant demands to adopt new, unfamiliar linguistic habits as well as to get rid of words and constructions we have grown used to our entire lives. These changes are easier to adopt for cognitive elites with strong verbal skills, for young people in social networking circles who most influence new norms, and for people who, for whatever reason, are psychologically comfortable with difference and diversity and rapid social change. Computer-mediated buzzwords in online crowdsourced dictionaries are not necessarily brand-new terms: they may be new ways of using existing words (e.g. gig, troll) or new ways of putting words together (e.g. drug driving, chillax). Whatever the reason for its present popularity, the buzzword is current and in sudden or increasing use and it is worth knowing what it means and how people are using it today. It might be quite an undertaking to guarantee whether a new word will stay in use for a long time or as a short-lived fad will disappear the moment people get sick and tired of it. Nevertheless, buzzwords permeate language learners' lives on various subject areas and present latest trends around the globe (splashed over the Internet, television, or newspapers).

\section{Computer-mediated discourse analysis}

Discourse analysis or discourse studies are aimed at analyzing written or oral language use, the study of meaning-making and meaningful communication. Laclau (1985) presenting the Essex School of discourse analysis provides innovative study of post-structural theory, post analytic thought and psychoanalysis to interpret identities, discourses and hegemonies. According to Brown and Yule (1983) discourse analysis is aimed at micro level of relations between sentences and utterances. Discourse analysis presents a complex linguistic issue which might integrate different aspects such as: psychological (cognitive, cultural-andhistoric, sociocultural, etc), linguistic (grammatical, textual, stylistic, etc), semiotic (semantic, syntactic, pragmatic, etc), philosophical (structural, post-structural, deconstructive, etc), logical (argumentative, rhetorical, etc).

As early as 1984, linguist Naomi Baron pointed out that computer-mediated communication is a powerful force in language change. The following 1990s saw the rise of a wave of computer-mediated discourse researchers (Baym, Cherny, Danet, Herring, Reid, Yates, etc) who described computer-mediated language and interaction making it far more complex and variable than considered earlier. Computermediated discourse exchanges are, on the one hand, faster than written exchanges via letters or published essays, yet still significantly slower than spoken exchanges. Furthermore, computer-mediated discourse allows multiple participants to communicate simultaneously which is hard to achieve in other media (Herring 1996) while at the same time the unseen or unknown audience create an impression of direct and even 'private' exchanges (King 1996). The public perception of computer mediated language used to be grammatically incorrect, incoherent or too simplified compared with academic written language; moreover, the range of vocabulary used to be deemed much narrower, less elegant or polished. Nowadays it is generally viewed that deliberate strategies of using non-standard features are aimed specifically to adapt the computer medium to Internet users' expressive and creative needs. It has nothing to do with so-called impoverished or simplified communication as well as diminished expressive functions of language. The richness and diversity of computer-mediated discourse is concentrated in multiple online human experiences and therefore enables to study interconnections between micro- and macro-levels of interaction.

Majority of scientific studies of computer-mediated discourse analyzed socio-psychological characteristics of an average Internet user in coherent sequences of sentences, propositions, speech or pragmatic turns-at-talk. Recent research on computer-mediated communication involves Internet-based social networking discourse and the objects of its analysis (discourse, writing, conversation, communicative event) are studied in 'naturally occurring' language use rather than invented or possible examples. The socio-psychological approach to computer-mediated discourse examines how digital media users manage interpersonal interaction, form and maintain relationship. Another branch of computer-mediated discourse examines paralinguistic features of emoticons to supplement and enhance language for people who embrace the technology. Other important topics are the effects of computer mediation on language change and its linguistic norms. As vocabulary acquisition is the largest and most important task facing the language learner (Swan \& Walter, 1990), the aim of the given article is to present vocabulary teaching approaches to computer-mediated language and their influence on students' acquisition.

\section{Computer-mediated vocabulary teaching principles}

Teaching and recycling key vocabulary is an integral part of students' language growth and requires careful planning and a diverse range of productive methodologies. It is noteworthy to mention that computermediated communication implies knowledge of the linguistic system, discourse patterns, technology as well 
as socio-cultural peculiarities. Learning vocabulary is a complex and time-consuming process; it still remains the matter of thorough practice requiring some general principles for successful teaching. According to Wallace (1982) the basic principles of efficient vocabulary teaching include aim, need, meaningful presentation, frequent exposure and repetition (or recycling). Knowing a word primarily involves the abilities to know its meaning, usage, word formation and grammatical form (Harmer 2001). To ensure storage of new vocabulary into long-term memory it is required to stick to specific principles (Thornbury 2002) summarized in Table 1.

Table 1. Vocabulary teaching principles for long-term memorization

\begin{tabular}{|c|c|}
\hline repetition & $\begin{array}{l}\text { Several encounters with a word over space interval during reading activities } \\
\text { online provide students with more chances to remember it for a long time }\end{array}$ \\
\hline retrieval & $\begin{array}{l}\text { Using the new vocabulary items in written tasks enable students to recall the } \\
\text { memorized words again in the future }\end{array}$ \\
\hline spacing & $\begin{array}{l}\text { Rather than to mass memory work in a single block it is preferable to split it } \\
\text { over a prolonged period of time }\end{array}$ \\
\hline pacing & $\begin{array}{l}\text { Putting a learner-centered approach into practice teachers should respect } \\
\text { different learning styles and individual pace so that memory work could be } \\
\text { done individually }\end{array}$ \\
\hline Use & $\begin{array}{l}\text { Realizing the so-called "Use it or lose it" principle it is recommended to put } \\
\text { new vocabulary items to practice in an interesting environment excluding } \\
\text { boring mechanic drills }\end{array}$ \\
\hline cognitive depth & $\begin{array}{l}\text { To remember the new items, it is vital to make more cognitively demanding } \\
\text { decisions, including creative thinking activities, case-studies or creative tasks }\end{array}$ \\
\hline personal organizing & $\begin{array}{l}\text { Adopting conversation and role-playing activities is important to personalize } \\
\text { vocabulary tasks that might significantly increase the probability of long-term } \\
\text { memorization of the target language }\end{array}$ \\
\hline imaging & $\begin{array}{l}\text { Associations with mental images or visualization of the new items are better } \\
\text { memorable than those that do not evoke with any pictures }\end{array}$ \\
\hline mnemonics & $\begin{array}{l}\text { Visuals and keyword techniques are best tricks to help retrieve the new } \\
\text { vocabulary stored in memory }\end{array}$ \\
\hline motivation & $\begin{array}{l}\text { Faced with appropriate challenging and engaging tasks even unmotivated } \\
\text { students can easily remember the new words }\end{array}$ \\
\hline attention & $\begin{array}{l}\text { A certain degree of conscious attention is an integral part of improving target } \\
\text { vocabulary }\end{array}$ \\
\hline
\end{tabular}

Source: Own results

\section{Computer-mediated vocabulary and its formation}

Computer-mediated communication reveals new forms of linguistic expressions, as well as stimulates a wide participation in heated debates on different social and political issues or serves for mere fun and entertainment. Many fads on social media as any form of collective behavior develop within a culture, a social group who enthusiastically follow the impulse for a finite period. Fads (or crazes) catch on when the number of people adopting it begins to increase to the point of being noteworthy but tend to fade away quickly when the perception of novelty is gone. The specific nature of the behavior associated with fads is intrinsically connected with new buzzwords:

- $\quad$ ice bucket challenge as a fundraising campaign to promote awareness of ALS involved a dumping of icy water on a person's head and daring others to do the same;

- Pokemon-going implied using the mobile device GPS to locate, capture, battle and train virtual creatures which appeared as if they were in the player's real-world location;

- catbreading went viral as a photo fad that involves taking pictures of cats with slices of bread placed round the neck;

- vadering also presents a photo fad that involves two people recreating the Star Wars scene in which Darth Vader uses the Force to grab an opposing character in a choke hold,

- horsemanning deriving its name from the Headless Horseman is a two-person pose where one person makes an impression of beheaded while another person hides behind an object, only leaving the head exposed in the picture;

- planking refers to the act of lying face down with arms to the sides in unusual public spaces; 
- the Kiki as one of the latest crazes involves people posting videos of themselves on Youtube jumping out of slow-moving cars while dancing to Drake's In My Feelings.

The term "chook" originated from Australia and New Zealand gave rise to a frozen chook phenomenon where naked people pretend to be frozen chicken carcasses in public. All photo fads are primarily aimed at sharing the picture online and typically present staged photos in which the subject poses in a specific manner (playing dead, face masking, lying down, owling, batmanning, teapotting, draping, etc). Unlike high-level engagement (such as volunteering, donating, protesting, etc.) the low-effort methods of engaging via clicking "share" or "like" are often characterized as 'slacktivism'.

On the other hand, social media platforms are increasingly cultivating large-scale changes, spurring high-level engagement and eventually contributing to public mobilization. Along with the special material (like lifestyle concepts of 'hygge', 'lagom', 'ikigai', 'gezellig', etc) the new terms and senses come into more frequent use in computer-mediated communication discourse. Thus, the Macmillan Dictionary has recently added new entries for neglexit (neglect of all other political problems because of Brexit) and 'backstop' (something that can be used to solve problems after everything else has been tried). Other new entries to online crowdsourced dictionaries prove that social media platforms (Facebook, Twitter, Youtube, etc) have contributed a great number of new phenomena based on rapid global changes in different spheres of human activity (Table 2).

Table 2. Neologisms in computer-mediated communication

\begin{tabular}{|c|c|c|}
\hline Social media & $\begin{array}{l}\text { Anthropocentric trend } \\
\text { Internet-inspired changes }\end{array}$ & $\begin{array}{l}\text { Selfie, humblebrag, virtue signaling, egosurf, p-phub } \\
\text { digital amnesia, password fatigue, Twitter quitter }\end{array}$ \\
\hline $\begin{array}{l}\text { Business } \\
\text { /Economy }\end{array}$ & $\begin{array}{l}\text { Changes in labour market } \\
\text { Wealth/ austerity }\end{array}$ & $\begin{array}{l}\text { elevator pitch, the gig economy, tollbooth economy } \\
\text { one percenter, austerians }\end{array}$ \\
\hline Politics & $\begin{array}{l}\text { Strong support/ or dislike } \\
\text { Brexit-inspired terms } \\
\text { American election season }\end{array}$ & $\begin{array}{l}\text { Russophobia, Corbynista, mobbing } \\
\text { Bregret, Bremain, Breturn, Regrexiteer } \\
\text { braggadocious, hopemonger, snowboat, press pen }\end{array}$ \\
\hline Way of life & $\begin{array}{l}\text { Food Fads } \\
\text { Hectic lifestyle }\end{array}$ & $\begin{array}{l}\text { zoodles, yo-yo dieting, arancini, uramaki, aquafaba } \\
\text { password fatigue; hurry sickness; junk sleep; fake-ation, }\end{array}$ \\
\hline $\begin{array}{l}\text { Gender and } \\
\text { sexuality }\end{array}$ & $\begin{array}{l}\text { Gender } \\
\text { tolerance }\end{array}$ & $\begin{array}{l}\text { Non-binary, third gender, theyby, demigender, } \\
\text { straightwashing, androgyne, rainbow }\end{array}$ \\
\hline
\end{tabular}

Source: Own results

The dispute on social media anthropocentric trend has been going on for a long time and the link between narcissism and social media use is quite apparent for psychologists and linguists. There is plenty of evidence of extreme selfishness, egotistic attitudes, pursuit of gratification from others or admiration for one's own qualities online. Narcissism seems to be on the increase or in some cases even epidemic (grandiose narcissism of extroverted and self-absorbed users; vulnerable narcissism of insecure neurotic counterparts). Facebook narcissism presents a specific phenomenon of excessive self love and is partly caused by a proliferation of celebrities whose indulgent lifestyle of pampering themselves in an idyllic environment is extremely contagious. Thus, Facebook narcissists broadcast information about themselves to a worldwide audience posting countless glamorous photos and pouty selfies, self-promoting content, and frequent status updates. Positive feedback and compliments boost their self-esteem and make them scroll through news feed obsessively as they are preoccupied with their social media presence. On top of that, this widespread self-promoting behavior online requires bragging in a modest or self-deprecating manner of humblebragging (e.g. I am exhausted from my two-week vacation to Hawaii. I need a vacation). By playing it down a brag statement is artfully planted to conceal pride that would otherwise be apparent. Furthermore, it is also argued that kind of inward-looking, self-obsessed attitude causes another egotistic trend recently dubbed egosurfing or searching the internet for occurrences of your own name (e.g. Egosurf. Google yourself. Find out how you show up online.) To some extent social media platforms might allow narcissists to engage in exhibitionistic, attention-seeking and self-promoting behavior but at the same time it might result in using bad language, direct verbal attacks or cyberbulling.

As the Internet represents the largest corpus of vocabulary, where users all over the world vote with their fingers, new words (or coinages) have been invented online to show recent changes between human and digital world. Thumbo is a mistake when you are typing with thumbs on a smartphone. Chatbot is a computer program that simulates human conversation through voice commands or text chats. Twitter quitter denotes a person who leaves twitter especially after being trolled. To express the latest trend of emotional correctness the social media thesaurus had been added with virtue signaling (the practice of saying or writing things that show you have the correct opinions about something) and SJW ("social justice warrior", a disparaging term 
for someone who holds and promotes socially progressive ideas, feminism, gender equality, multiculturalism, etc. To favour emotions and beliefs and neglect or ignore objective unbiased data the word 'post-truth' has been introduced speaking about political campaigns, candidates or even era in general. 'Post-fact' continues this trend relating to a society or situation in which feelings or instincts are more highly valued than facts, which are regarded as not being fixed or always true.

An excessive use of social media and society's increasing over-reliance on technology which might lead to issues with memory and cognitive skills resulted in a number of neologisms in digital sphere. Digital amnesia presents a phenomenon in which people readily forget important information in the belief that it can be immediately retrieved from a digital device. Digital dependence is eroding human memory as people have become accustomed to using computers devices as an "extension" of their own brain (Kaspersky Lab term). Similarly, the term "digital dementia" is used to describe how overuse of digital technology leads to a breakdown of cognitive abilities.

Computer-mediated communication triggers new vocabulary to describe interpersonal or family issues as well. From unnecessary Instagram hashtags to unflattering 'happy birthday' selfies 'performative friendship' is a means to celebrate a friendship online but ends up making it all about them. 'Skype family' is used to denote a family where one parent lives in a different country from other parent and children. Switch and swipe generation is widely used as a marketing term coined to describe young people who are readier to change jobs, homes, sexual partners than older generations. 'Sandwich generation' is a generation of people in their forties responsible both for bringing up their own children and the care of their ageing parents. The problem of longevity and ageing population contributed to new entries like 'unretired' to speak about still working people even though they have officially reached the age when they have to stop working. The use of 'grey gapper' or 'grey vote' emphasize active social roles of older people over 55 who are either considered as ardent travelers to distant and exciting places or potential voters in an election.

Having examined the new entries in the Open Dictionary, we conclude that changes in lifestyle area contributed to a number of new blend or portmanteau words in computer-mediated communication, such as: hacktivist (a person who gains unauthorized access to computer files or networks in order to further social or political ends); eco-bling (ecological technology that cost an amount of money that you will never get back in terms of energy saved or produced); tweet-up (a meeting of two or more people who know each other through the Twitter short messaging service); Winterval (a mixture of Winter and Festival to denote a made up holiday that occurs in December for people of all different beliefs to worship rampant consumerism); bleisure (a blending of business-oriented trips with personal time); foodoir (a written description of someone's experiences which includes recipes or focuses on food); fauxmance (a fake romance for the benefit of the media or family and friends); framily (people who are not related to you but are your very close friends and are as important to you as your family); mononymous (a person known by just one name in today's online culture of anonymity).

In linguistics the process of morphologically joining two or more parts to form a compound lexeme is an effective way to come up with new notions. In a changing world it is quite undemanding to take a couple of familiar words and fuse them together to get a fresh collocation (liquid biopsy, dude food, binge-watching, rage room, meat-free, yo-yo dieting, wash-up meeting, etc). The first type of new compounds consists of at least two stems which are derived and inspired from the old parts (fast food later triggered fast fashion making fashion trends quickly and cheaply available to consumers; outsource has recently led to insource). Similarly, based on the buzzword 'snowflake' (used disapprovingly about a young person, who is considered to be too sensitive and easily offended bother people's opinions) the shortlist of Oxford Dictionary Word of the 2017 was added with the term "broflake" for a man who is readily upset or offended by progressive attitudes that conflict with his more conventional or conservative views. (e.g. there was predictable disquiet from various broflakes on social media) 'Nonliner' (a person who never or very rarely uses the Internet usually because they don't have access to it) is a play on 'onliner' blending this word with the prefix non-, meaning 'not'.

Most compounds in open crowdsourced dictionaries present a sum of two parts which build up a new word (sealion, clutch hitter, gaslight, meat-free, brain freeze, uncanny valley, etc.). But some compounds may not have any literal or metaphorical connection to the original phenomenon or a concept. For instance, having gone viral in 2017 and chosen the word of the year in Australia the internet slang compound 'milkshake duck' presents a quirky notion. It refers to a person who rapidly becomes famous for something wholesome before they are revealed as a deeply flawed character with terrible opinion or a distasteful or offensive past. In the age of social media, the concept of milkshake duck is more about instant virality and the growing polarization of publicly professed ideologies. The viral component means that anyone might become famous overnight, but it also means that an increased fame might trigger further research and reveal negative or controversial things so that a person will become the object of hatred or ridicule. Milkshake duck is the product of social media savvy community who can either embrace and worship or destroy and discard an individual with equal ease. 
Based on adding suffixes to the base or stem or a word (e.g. feminism, sexism, racism) the new concept 'motherism' was formed to denote a lack of respect for full-time mothers who are deemed as ugly unintelligent slackers. The derogatory cliché of 'self-lobotomized' stay-at-home mums are not necessarily supported by leading child development experts but remains controversial and disputable. The lifestyle choice of a full-time parent does not imply that they take a downward step socially or intellectually. The damaging prejudice against mothers who choose to look after their children and are not involved in formal employment appeared as a result of political and economic agendas. Using the derivational pattern of 'feminist' and 'womanist' a new entry 'motherist' advocates motherhood and full-time parenting.

The prolific use of two opposing meanings of suffixes -ism/ist continues to serve a pattern for further word formation and might refer to either a prejudice (racism/rasist) or on the contrary can indicate ideological support (feminism/feminist). Thus, the dietary practice of eating uncooked, unprocessed and often organic food is rawism, whereas activists are called raw foodists or rawists. In blogosphere the notion 'singlism' is the stigmatizing of adults who are single. It includes negative stereotyping and discrimination of singles. 'Singlist' is used disapprovingly to speak about a person who behaves unfairly towards unmarried people.

After the Global Financial Crisis, the policy to restrain public and private spending became the only possible solution to tackle budget deficit. Austerity measures led to austerianism as an economic theory to cut down on government spending during economic recession. The neologism 'austerian' is a portmanteau of 'austerity' and 'Austrian' (School of Economics) and relates to fiscal conservatism. 'Austerians' are economists who advocate cutting government expenditures, particularly social spending.

In current English it is increasingly common to use plural pronoun they to refer to a singular gender pronoun (he/or she). It should not be considered as a sign of declining standards or ungrammatical. It is widely accepted both in speech and in writing to represent a gender-neutral approach. "Tell each student that they can hand in their paper a day late". The gender-neutral ' $M x$.' which is being used increasingly on various official forms in the UK serves as a title for those who do not identify as being of a particular gender, or for people who simply do not want to be identified by gender. In 2018 nonbinary (meaning neither male nor female) gender identity was recognized in several American states and some advocate that gender should be removed entirely from IDs. The category 'third gender' recognizes three or more genders. The bill on third gender option allows intersexual people to register as 'divers' ('miscellaneous' or 'other'). Theyby' is another recent concept for parents to bring up their off-spring in gender-neutral fashion.

Another area that has been explored extensively for Internet communities is gender asymmetry. While some researchers of computer-mediated communication reveal gender differences and dominant male strategy (Herring 1996) others are emphasizing monumental gender gap that persists all over the world. More than 90 percent of American public monuments are dedicated to men thus more campaigns are aimed at raising money to break the bronze ceiling and recognize and honour contribution of women to a city or a country. At the moment bronze statues have become an issue of political dispute to increase female representation in monuments as well as street names, public art and appointed commissions.

Gender pay gap or the difference between what the median male employee is paid and the median female employee is paid, expressed as a proportion of male earnings. The belief that women and girls can do anything they dream of popularized the notion 'girlpower'. Due to social movement for greater equality and representation Kim Kardashian tries to break a pixel ceiling releasing a new pack of feminist KIMOJI and girlpower slogans (Slay In Your Lane, Grab America Black)

As computer-mediated communication instigates debates on relevant political or economical issues a large number of buzzwords reflect positive or negative attitude of active social media users. Rise of YIMBYs (Yes In My Backyard) are progressive housing activists that have emerged from Seattle to Sydney, Austin to Oxford, lobbying for housing development. Their lives are threatened by skyrocketing rental prices and housing shortages and they support dense urban construction projects whereas NIMBYs (Not In My Back Yard) oppose building projects and preserve the environment, prevent an influx of immigrants, etc. NIMBY supporters oppose projects such as homeless shelters that might bring social problems into the neighborhood, sports bars because of noise or casinos. The YIMBY movement started in San Francisco in 2013 and then spread around the globe changing the legislature for affordable living conditions. NIABY (an acronym for Not In Anyone's back Yard) presents a more universal stand on the problem opposing only unwise or inappropriate developments like drug houses, toxic waste dump or nuclear plants.

If BANANA (Build Absolutely Nothing Anywhere Near Anything/Anyone) movement is against publicly funded projects and private developments, they claim it might harm others' businesses, ruin the landscape, cause traffic gridlocks, etc. $C A V E$ standing for Citizens Against Virtually Everything is a general term to denote activists who oppose new infrastructure, bridges or underground lines, public transport or stadiums.

To emphasize a specific social position of citizens computer-mediated communication participants generate various set-expressions or idioms (e.g. Kick the can down the road means to delay dealing with a 
serious problem hoping it will go away. Similarly, to sit on your hands means to not take action when you should (Regulators sat on their hands and did nothing)

Analyzing computer-mediated communication linguists register economic concepts and their latest trends in shifting cultural and business environment. More businesspeople are estimated to become independent contractors or work in short-term jobs that can improve work-life balance. 'Elevator pitch' is a proposal which is short enough to give in the course of a ride in a lift or elevator. The word ' $\mathrm{gig}$ ' is used to describe any piece of work that you do for money, especially if you are self-employed (a typing/gardening/writing gig). As computer-mediated communication instigates heated discussions on economical issues a vast list of economically-related terms has spurred including:

- 'Gig economy' presents an environment in which temporary positions are common and organizations contract with independent workers for single projects or tasks for which a worker is hired (limited overlap with skill sharing).

- Sharing economy' or peer-to-peer based sharing highlights the preference to rent or borrow goods in ways that improve efficiency, sustainability and community

- 'Gift economy' relies on intangible rewards like a sense of contribution, community or prestige

- 'Barter economy' is a cashless economic system when services or goods are traded at negotiated rates.

- 'Concierge economy' includes anything that puts items or devices in front of customers before they realize they need it.

New economy models also include collaborative economy, freelance economy, peer economy, crowd economy, platform economy, digital economy, etc. Moreover, one platform can fall under multiple definitions (e.g. partly on-demand, gig, collaborative, sharing) and it is crucial to understand these nuances.

\section{Conclusions}

As the above discussion shows, computer-mediated discourse is valuable in providing thorough practice for language learners to discuss the latest changes in social and political life around the globe. (mostly through reading and writing). Thus, new ways of learning and teaching vocabulary are enabled by computermediated communication. Computer mode provides greater learner participation, involvement in discussions and turn-taking initiation. Computer-mediated discourse study enables us to see interconnections between micro- and macro-levels of interaction. Cyberspace provides valuable options for collaboration (online projects, distance learning, forums, videoconferencing, etc) and opportunities for learner's autonomy. The teacher's role is also changed from an authoritarian fountain of knowledge to a guiding 'e-moderator'.

Communication generated in computer-mediated environment contributes to a rich and diverse vocabulary use. As social media continues to thrive and it is embraced by more and more people an Internet slang or a meme ('facepalm', 'bae', 'milkshake duck', 'unicorn milkshake', 'mic drop') might become extremely popular and they are added to online dictionaries as new words (e.g. 'bicoin', 'twerk', 'derp', 'tl;dr', etc). The new entries into open online dictionaries show a vast variety of economical reforms, new technological and cultural phenomena or even instigate global social movements. The year of 2017 saw a trace of positivity whose lexical characterization was significant enough to select 'youthquake' as the word of the year, which is undoubtedly a refreshing antidote to the divisive overtones of new entries as fake news, post-truth, broflake. This might initiate further discussions on a large-scale impact of computer-mediated communication on social changes as scientists, economists or politicians use social media as a powerful tool to address major concerns promoting science, exploring new career options, influencing policy, engaging with the public about environmental issues.

\section{Acknowledgements}

The article is written within the research work on the topic "Cognitive and communicative factors of reality representation in different types of discourse" (research contract of 04.06.2018, № 1/326, contract owner Mordovian state pedagogical institute named after M.E. Evseviev). 


\section{References}

Angeli C, Valanides N, Bonk CJ (2003) Communication in a web-based conferencing system: the quality of computer-mediated interactions. British Journal of Educational Technology 34(1):31-43. doi: 10.1111/14678535.d01-4

Baym, NK (1996) Agreements and Disagreements in a Computer-Mediated Group. Research on Language and Social Interaction 29:315-346. doi: 10.1207/s15327973rlsi2904_2

Brown G, Yule G, Discourse Analysis, $1^{\text {st }}$ edn. (Cambridge: Cambridge University Press, 1983), 288 p.

Cherny L, Conversation and Community: Chat in a Virtual World, $1^{\text {st }}$ edn. (Stanford: CSLI Publication, 1999), 369 p.

Crystal D, Language and the Internet. $1^{\text {st }}$ edn. (Cambridge: Cambridge University Press, 2003), 272 p.

Danet B, Text as Mask: Gender, play, and performance on the Internet. In: S.G. Jones (ed). New media cultures, Vol.2. Cybersociety 2.0: Revisiting computer-mediated communication and community. (Thousand Oaks, CA, US:Sage Publications, 1998), pp.129-158.

Herring SC, Posting in a different voice: Gender and ethics in computer-mediated communication. In: C. Ess (ed.), Philosophical Perspectives on Computer-Mediated Communication (Albany: SUNY Press, 1996), pp.115-45.

Harmer J, The practice of English language Teaching, $3^{\text {rd }}$ edn. (London: Longman ELT, 2001), 384 p.

Hymes D, Foundation in Sociolinguistics: An Ethnograthic Approach, $1^{\text {st }}$ edn. (Philadelphia: University of Pennsylvania Press, 1974), 260 p.

Jiang L, Bazarova NN, Hancock JT (2013) From perception to behavior: Disclosure reciprocity in computermediated and face-to-face interactions. Communication Research, 40: 125-143. doi: $10.1177 / 0093650211405313$

King SA (1996) Researching Internet Communities: Proposed Ethical Guidelines for the Reporting of Results. The Information Society, 12 (2): 119-128. doi: 10.1080/713856145

Laclau E, Mouffe C, Hegemony and Socialist Strategy: Towards a Radical Democratic Politics, $1^{\text {st }}$ edn. (London: Verso, 2001), 197 p.

Lisin E, Lebedev I, Sukhareva E., Komarov, I (2014) Analysis of scenario of structural and technological modernization of the power industry in the context of competitive electricity markets. International Economics Letters 3(3):105-114. doi: 10.24984/iel.2014.3.3.3

Macmillan Dictionary (2018) http://www.macmillandictionary.com Accessed 28 July 2018

McQuail D, Mcquail's Mass Communication Theory, 6th edn (London: SAGE Publications Ltd, 2010), 632 p.

Mitsche N, Strielkowski W (2016) Tourism e-services and Jewish heritage: a case study of Prague. European Journal of Tourism, Hospitality and Recreation 7(3):203-211. doi: 10.1515/ejthr-2016-0022

Ragulina Y V, Semenova E I, Zueva I A, Kletskova EV, Belkina E N (2018) Perspectives of solving the problems of regional development with the help of new internet technologies. Entrepreneurship and Sustainability Issues 5(4)890-898. doi:10.9770/jesi.2018.5.4(13)

Reid E, Hierarchy and Power: Social control in cyberspace. In: M. Smith and P. Kollock (eds). Communities in Cyberspace. (London \& New York: Routledge, 1999), pp. 107-33.

Strielkowski W (2017) Promoting Tourism Destination through Film-Induced Tourism: The Case of Japan. Market-Trziste 29(2):193-203. doi:10.22598/mt/2017.29.2.193

Swan M, Walter C, The New Cambridge English Course 2 Student's Book, $1^{\text {st }}$ edn (Cambridge: Cambridge University Press, 1990), 128 p.

Thornbury S, How to teach Vocabulary, $1^{\text {st }}$ edn. (Harlow: Longman, 2002), 185 p.

Van Dijk TA, Kintsch W. Strategies of Discourse Comprehension (New York: Academic Press, 1983), 389 p. 
Wallace MJ, Teaching Vocabulary, $1^{\text {st }}$ edn. (London; Exeter, NH: Heinemann Educational Books, 1982), $144 \mathrm{p}$.

Yates SJ (1993) The Textuality of Computer-Mediated Communication: Speech, Writing and Genre in CMC Discourse, a thesis presented for the defense of $\mathrm{PhD}$, Open University

Zielińska A (2016) Information is a market products and information markets. Czech Journal of Social Sciences, Business and Economics 5(4):31-38. doi: 10.24984/cjssbe.2016.5.4.4

Zizek S, Interrogating the Real, $1^{\text {st }}$ edn. (New York: Bloomsbury Academic, 2006), 392 p. 